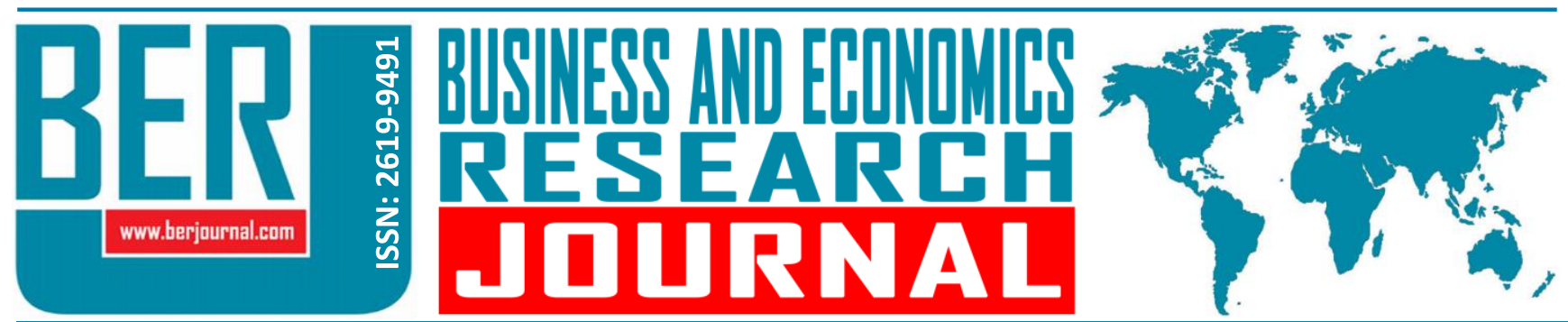

Business and Economics Research Journal Vol. 10, No. 2, 2019, pp. 499-515 doi: 10.20409/berj.2019.182

\title{
Russian Consumers' Responses to Turkish Products: Exploring the Roles of Country Image, Consumer Ethnocentrism, and Animosity
}

\author{
Inci Dursun ${ }^{\mathrm{a}}$, Ebru Tumer Kabadayi ${ }^{\mathrm{b}}$, Kutalmis Emre Ceylan ${ }^{\mathrm{c}}$, Cansu \\ Gokmen Koksal $^{\mathrm{d}}$
}

\begin{abstract}
The main objective of this study is to investigate the country of origin (COO) effect on purchase decisions for Turkish products in foreign markets. Particularly, the study focused on the impacts of country image, consumer ethnocentrism, and animosity on product evaluation, risk perception and buying intention of Russian consumers. The data was collected through a survey conducted on a sample consisting of 346 native Russian consumers living in Moscow. Analysis results revealed that origin related factors (i.e. country image, consumer ethnocentrism, and animosity) do not directly influence purchase intention for Turkish products. Animosity was found to increase the perceived risk of buying Turkish products, to some extent, while expected negative impacts of ethnocentrism were not confirmed. Most importantly, findings revealed a strong link between country image and product evaluation. Results were discussed in detail and the article concludes with implication of the findings.
\end{abstract}

Keywords: Country of Origin (COO), Country Image, Ethnocentrism, Animosity, Turkish Products

JEL: M16, M31, M39

Received : 31 October 2018

Revised : 31 December 2018

Accepted : 15 February 2019

Type : Research

\section{Introduction}

Export growth is seen by governments around the world as a central strategy for economic growth in the new global landscape, even in nations with large domestic demand, such as the United States (Griffith \& Czinkota, 2012). Export-led development strategies are increasingly recommended, specifically for developing nations (Kumcu, Harcar \& Kumcu, 1995). Despite the high growth rates of export sales, which reaches to 20.9 percent in the 2001-2006 period (Aydın, Sayglı, \& Saygılı, 2007), Turkey still suffers from the significant level of trade deficit (TUiK, 2018). In this context, it is a critical issue for Turkish researchers and policymakers to understand the dynamics of and promote a long-term sustainable export growth which is in turn related to economic growth performance of the country.

Exporting is also beneficial for firm performance since "it utilizes idle operating capacity and improves production efficiency; it raises technological, quality, and service standards in the organization; it strengthens

a Asst. Prof., PhD., Gebze Technical University, Department of Business Administration, Kocaeli, Turkiye, incidursun@gtu.edu.tr (ORCID ID: 0000-0002-9856-3914)

b Prof., PhD., Gebze Technical University, Department of Business Administration, Kocaeli, Turkiye, tumer@gtu.edu.tr (ORCID ID : 0000-0002-0673-6866)

Asst. Prof., PhD.,Istanbul Gelisim University, Institute of Social Sciences, Department of Business Administration, Istanbul , Turkiye, mailto:keceylan@gelisim.edu.tr,(ORCID ID: 0000-0002-2419-8985)

d Res. Asst., Gebze Technical University, Department of Business Administration, Kocaeli, Turkiye, ckoksal@gtu.edu.tr (ORCID ID : 0000-0001-9139-0451) 
the company's arsenal of competitive weapons; it provides a better profit base to reward shareholders and employees; it generates more funds for reinvestment and growth; and it diversifies business risks by operating in multiple markets" as summarized by Leonidou (2000: 121). However, there are factors which impede firms' export performance covering different consumer habits/attitudes and cultural traits (see Leonidou, 1995; 2000 for review). In this context consumers' attitudes, responses and preferences towards products of foreign origin also emerge as a critical factor. In marketing literature, there are a number of studies that focus on "country-of-origin" (COO) effect which has an important role in consumers' perception, decision making, and purchase behaviors as related with products that are made in a particular/foreign country (e.g. Nagashima, 1970; Bilkey \& Nes, 1982; Han \& Terpstra, 1988; Kaynak \& Kara, 2002).

$\mathrm{COO}$ is considered as a phenomenon which influences consumers' perceptions about a product, plays a halo effect or a summary effect in product evaluation and shapes the consumers' decision process as an extrinsic cue (Saran \& Gupta, 2012). In addition to its role with cognitions, COO also relates to emotions, identity, pride and autobiographical memories (Verlegh \& Steenkamp, 1999: 523). Empirical findings revealed that COO may have both negative and positive effect on purchase intentions (Klein, Ettenson, \& Morris, 1998; Knight \& Calantone, 2000; Lala, Allred, \& Chakraborty, 2008; Genç \& Bayraktaroglu, 2017). From the firms' perspective, it means that $\mathrm{COO}$ effect may provide a competitive advantage or disadvantage based on the consumers' abstract attitudes to the products originated from the respective country. Accordingly, when consumers in the international market have negative attitudes to the products that are made in a particular country it builds a barrier for firms from that country. Hence, it is critical to understand the $\mathrm{COO}$ effects to build effective international marketing strategies for Turkish firms. While the studies on effects of $\mathrm{COO}$ and related factors are generally carried out in the context of developed countries (e.g., America) the studies on perceptions of products originated from developing countries (e.g., Turkey) are seen to be relatively rare (Canli \& Maheswaran, 2000; Demirbag, Sahadev, \& Mellahi, 2010). To bring future insights to the current understanding of international consumers' response to products originating from Turkey, to some extent, this research focuses on $\mathrm{COO}$ effect in the consumer market in Russia Federation (Russia afterward). As indicated by Şimşek, Şimşek, \& Zhanaltay, (2017), although trade relations between Turkey and Russia have steadily developed over the last 23 years the trade balance between these countries has been mostly in the favor of Russia mainly because of the large scale of raw material import of Turkey. The researchers also emphasize the advantage that the structure of Turkish exports to Russia transform from low value-added products to high value-added products (Şimsek et al., 2017: 8). So, it is important to understand Russian consumers' attitudes to final products originated from Turkey that may help to Turkish firms to design and implement effective marketing communication programs to encourage a positive consumer response. In this context, this research focuses on Russian consumers' quality evaluation, risk perception and purchase intention for the products from Turkey and the effect of COO in the process. COO is investigated through an interaction between country image (Lee \& Ganesh, 1999; Knight \& Calantone, 2000; Lala et al., 2008); consumer ethnocentrism (Suh \& Kwon, 2002; Nijssena \& Douglas, 2004; Yoo \& Donthu, 2005; Ishii, 2009; Josiassen, Assaf, \& Karpen 2011), and consumer animosity (Klein et al., 1998; Klein, 2002; Nijssen \& Douglas, 2004; Nakos \& Hajidimitriou, 2007; Maher \& Mady, 2010; Wang, He, \& Li, 2013) which all have contributed to explaining the purchase intention for a product from a particular/foreign country. Doing so, this research may provide a comprehensive understanding regarding the antecedents of Russian consumers' intention to buy "made in Turkey" products. In this respect, the literature on the country image, consumer ethnocentrism, and animosity are briefly reviewed, followed by the presentation of the theoretical framework and research hypotheses. The method which is used to collect the data and test the formulated hypotheses are described, and analysis results are discussed in detail. Finally, the managerial implications, limitations of the study and directions for future research are provided.

\section{Literature Review}

\subsection{Country of Origin (COO) Effect and Country Image}

From the information processing perspective consumer buying decision is "viewed as a net through which an array of cues passes" (Bettman, 1970: 370). Accordingly, product accept-reject decisions of an 
individual consumer depend on those cues which fall into "three basic categories including (1) choice object attributes, (2) external environmental attributes and (3) internal cues or cognitive variables such as perceived risk (Bettman, 1970). Thus, evaluation of product attributes and perceived risk are interrelated key factors for all buying decisions. So, it is safe to propose their interaction and impacts on buying intention for products from a foreign country. These propositions are supported by findings of numerous studies (e.g. Nagashima, 1970; Lumpkin, Crawford, \& Kim, 1985; Samiee, 1994; Agarwal \& Teas, 2001; Lee \& Chen, 2008; Demirbag et al., 2010).

However, for a clear understanding of the purchase decisions for foreign products a specific informational cue, namely $\mathrm{COO}$, which is also called "made in" concept should be analyzed. Information processing view indicates that consumers use both intrinsic (e.g., performance, design, taste, fit) and extrinsic cues (e.g. brand image, store image, advertising, price, warranties) as a basis for evaluating the product (Olson \& Jacoby, 1972; Han \& Terpstra; 1988). COO is considered as an external cue that may have an influence on product evaluation, perceived risk, purchase intention and behavior (Bilkey \& Nes, 1982). Consequently, the phenomenon referring to any influence, positive or negative, that the country of manufacture might have on the consumer's choice processes or subsequent behavior is identified as "COO effect" (Elliott \& Cameron, 1994: 50). In 2006, Usinier reported that more than 1000 studies (at least 400 of them were published in academic peer review journals) were conducted to explain how COO influences the consumers' response to the brand or product. In his review and meta-analysis, Liefeld (1993) concluded that the effect of $\mathrm{COO}$ on consumer product evaluations was significant, even though the impact varies between products and consumer markets.

A number of studies explain why consumers have more favorable attitudes and response to the products of one country in comparison to another. In this point "country image" appears as a significant indicator. The country image is conceptualized in different ways based on the route of its effect. The structural interrelationship between the country image and beliefs about products attributes and brand attitudes is explained in two ways including halo effects and summary effects (Han, 1989; Martin \& Eroğlu, 1993; Lala et al., 2008). Accordingly, consumers may rely on country image to infer the quality when they are unable to detect the true quality (halo effect), or country image may help them summarize their product beliefs and directly affect their brand attitudes, especially when they are familiar with the products originated from a particular country (summary effect). In other words, when consumers are unfamiliar with the product made in Turkey, they will use general attitude about Turkey to infer the products attributes and when they have some experience with Turkish products their evaluation will be influenced from the summary information they gained from the past experiences. Although, Russian consumers may have some experiences about Turkish products because of ongoing trade relations this study follows the halo effect approach with the assumption that Russian consumers' perceptions about Turkey are likely to be affected by meandering relations between two countries (Özbay, 2011), which in turn may affect their purchase decisions.

According to halo effect perspective, a country name works similarly to brands in consumer mind (Koo Kim, 1995) and so it has a similar effect with the brand image. The valence and the strength of COO effect depend, among other things, on the image of the respective country. Here, the country image is distinct from product image and refers to the total of all descriptive, inferential and informational beliefs, impressions, ideas and emotions about a country which are formed based on a personal frame of reference (Kleppe, Iversen, \& Stensaker, 2001). This image may develop through various ways such as (1) a direct experience with the country, (2) information from outside sources such as word of mouth communications, and (3) inferences (correct or incorrect) based on past experiences with the products originating in that particular country (Martin \& Eroğlu, 1993). Samiee (1994) highlights the small role of product related believes for building a country image in consumers' mind. Instead, the image of a country is an abstract attitude comprising the particular attitudes towards a country's territory, history, and traditions, its domestic economy, public culture, norms, and values as well as its political organization (Buhmann, 2016). In this study, country image is conceptualized from a cognitive perspective as a multi-dimensional concept comprising the 
dimensions of economic conditions, political structure, vocational training, and work culture (e.g. Martin \& Eroğlu, 1993; Lala et al., 2008).

Once an image is formed in consumers' mind it leads to the stereotyping of objects and it is used as the basis for strong explanations, and therefore strong chains of beliefs (apothegms) about image objects and related objects (Papadopoulos, 1993). So it is reasonable to expect that once a country image is formed it will spread to the product related belief that is made-in, designed-in, or invented in that country. Indeed, as indicated by Papadopoulos, (1993: 9) "the use of place-of-origin to evoke the image of everything from persons to ideas and products can be traced to antiquity. From "Joseph of Arimathea" and "Greek mythology" to "Chinese silk" and "German engineering," origin has played a significant role throughout history in enabling people to identify, classify, assess, think of, and act upon phenomena and object". Obviously, country images can give a beneficial reputation to the entire product category such as German cars, French wines or even cause branding (e.g. Cafe' de Colombia) (Kotler \& Gartner, 2002). For example, the value a consumer gives to a perfume produced in France helps feed any French perfume produced in France from the positive connotations and relationships of the French perfume industry (Amonini, Keogh, \& Sweeney, 1998). This can be attributed to the impact of the country's image on evaluations of product-related elements such as price, value, design, service, and excellence.

There are some other roles that the country image and its particular dimensions play on foreign products buying process. First of all, economic and technologic development of the country, which is a prominent aspect of the country image, is found to be related to consumers' choices (See, Samiee, 1994 for a review). This is presumably because there is a close relationship between the level of development of countries and the skills and technology required for the production of products (Porter, 1999). Consistently, consumers have negative perceptions and low purchasing intentions for products produced in countries with a high risk of performance (Verlegh \& Steenkamp, 1999; Demirbag et al., 2010). For example, while the products produced in developing countries are perceived as less technology intensive and less sophisticated and lower quality, it is seen that the products of developed countries such as USA and Germany are perceived as better quality, luxury, premium and technological. It appears that country development perceptions govern the quality and risk perceptions of products (Bilkey \& Nes, 1982; Demirbag et al., 2010; Akdeniz \& Kara, 2014). Secondly, the country image also comprises the perceptions about the competence of workers who live and work in that country. It is reasonable to expect that well educated, hard- working and highlytrained workforce would improve the quality, durability, and design of the products. Consistently, it was found that, when most consumers learn that the products are made in China, they are prone to perceive /evaluate them as a copycat imitation with low quality and poor workmanship (Akdeniz \& Kara, 2014). And finally, the country image may influence purchase decisions because they promote positive and/or negative emotional associations with particular nations (Verlegh \& Steenkamp, 1999). In this context, perceptions regarding the political structure of the origin country may bias consumers' evaluations of products and purchase related risk through effective connotations. Previously, attitudes toward the political system of the country were found to be impactful on consumers' accept-reject decisions (e.g. Wang \& Lamb 1980). Considering the congruent grounds provided by literature we expect that country image will affect the judgments about Turkish products and intention to buy:

H1: When consumers have a more favorable country image of Turkey, their evaluation of the Turkish products will improve.

H2: When consumers have a more favorable country image of Turkey, the perceived risk of buying Turkish products will decrease.

H3: When consumers have a more favorable country image of Turkey, their intention to buy Turkish products will increase.

\subsection{Consumer Ethnocentrism}

Consumer ethnocentrism (CE) is a concept that is adapted to the consumption domain by Shimp and Sharma (1987) from a pure sociological concept of ethnocentrism introduced by Sumner (1906). In sociology 
literature, ethnocentrism is defined as ethnic group self-centeredness and operationalized as a preference for the in-group over outgroups, the association of positive in-group attitudes and negative outgroup attitudes or primarily as generalized outgroup negativity (Bizumic, Duckitt, Popadic, Dru, \& Krauss, 2009). Ethnocentrism leads individuals to unquestioningly embrace anyone or anything in their identifying group and to systematically reject all which falls outside of this group (Hult \& Keillor, 1994). When applied to the domain of consumption, ethnocentrism (CE) is defined as the "beliefs held by consumers about the appropriateness, specifically morality, of purchasing foreign made products" (Shimp \& Sharma 1987: 280). In consumer behavior literature, $\mathrm{CE}$ is considered as a phenomenon that provides a valuable explanation of why some consumers have negative orientations toward foreign products by focusing consumers' cognition and emotions as they relate to products from other countries (Shimp, 1984).

As a trait-like property of individuals' personalities, ethnocentrism is formed in early childhood socialization and carried into adulthood with few changes (Shimp, 1984; Shimp \& Sharma, 1987; Sharma, Shimp, \& Shin, 1995). In this period it improves in a constellation of some social-psychological and demographic influences (Sharma et al., 1995) such as conservation types of personal values (Balabanis, Melewar, \& Mueller, 2002; Javalgi, Khare, Gross, \& Scherer, 2005), patriotism (De Ruyter, Van Birgelen, \& Wetzels,1998; Klein \& Ettenson, 1999; Balabanis, Diamantopoulos, Mueller, \& Melewar 2001; Javalgi, Khare, Gross, \& Scherer, 2005; Vida \& Reardon, 2008; Ishii, 2009; Rybina, Reardon, \& Humphrey, 2010), war and economic animosity (Klein \& Ettenson, 1999; Ishii, 2009; Nijssen \& Douglas, 2004; Cai , Fang, Yang, \& Song, 2012), national identity and nationalism (Vida, Dmitrovic' \& Obadia, 2008), materialism (Cleveland, Laroche, \& Papadopoulos, 2009), cultural orientations such as collectivism toward parents and coworkers (Sharma et. al., 1995; De Ruyter et al., 1998; Javalgi et al., 2005), masculinity and uncertainty avoidance (Yoo \& Donthu, 2005) some life style facets such as strong-mindedness (Spillan, Kang, \& Barat, 2011) and concerns regarding personal finance, country economy (Klein \& Ettenson, 1999) and political posture (Javalgi et al., 2005). Literature also provides evidence that ethnocentric and non-ethnocentric consumers differ in demographic characteristics. It is generally reported that female (Sharma et al., 1995; Javalgi et al., 2005; Josiassen et al., 2011,), older consumers (De Ruyter et al., 1998; Javalgi et al., 2005; Josiassen et al., 2011), with lower-income (Shimp, 1984, Sharma et al., 1995) and lower education (Shimp, 1984, Sharma et al., 1995, Klein, \& Ettenson, 1999) exhibit relatively higher ethnocentric tendencies. On the other side, previous findings regarding the antecedents of CE highlighted some hindering factors. Accordingly, ethnocentric tendency of a consumer is diminished by cultural and global openness (Sharma et. al. 1995; De Ruyter, et al., 1998; Suh \& Kwon, 2002), global consumption orientation (Alden, Steenkamp, \& Batra, 2006), long-term orientation (Yoo \& Donthu, 2005), cosmopolitanism (Vida \& Reardon, 2008; Cleveland et al., 2009; Rybina et al., 2010), internationalism (Ishii, 2009) and some consumption habits such as need for uniqueness, role-related consumption and status consumption (Ranjbarian, Barari, \& Zabihzade, 2011).

As a dimension of the general attitude toward foreign products (Shimp, 1984) CE helps to predict international consumers' responses to marketing activities for products manufactured abroad. The effects of the ethnocentric tendency in consumer decision making rooted in love and concern for one's own country and the fear of harmful effects that imports may bring to oneself and countrymen (Sharma et al, 1995). Accordingly, consumers with high ethnocentric tendencies avoid purchasing foreign made products because they believe it will hurt the domestic economy, cause the loss of jobs and, in short, because they consider it as unpatriotic (Shimp, 1984). As a specific property, an ethnocentric individual view own group as superior, strong, and honest while seeing groups as inferior, weak, and dishonest troublemakers (Sharma et al, 1995). In a similar vein, ethnocentric consumers are likely to evaluate domestic products unreasonably favorable (Supphellen \& Rittenburg, 2001) while underestimating the quality of foreign products. Indeed, from the perspective of consistency theories, consumers with ethnocentric tendency are expected to make a biased evaluation of the foreign products with the need for consistency they believe that buying those products are not moral. Although there has been some conflict in findings, past research revealed impressive evidence regarding negative impact of CE on product judgments (Klein et al., 1998; Klein, 2002; Suh \& Kwon, 2002; Nijssen \& Douglas, 2004; Nguyen, Nguyen, \& Barrett, 2008; Ishii, 2009; Funk, Arthurs, Treviño, \& Joireman, 2010) supporting the expectation. Hence, it is purported that the extent of the ethnocentric tendency is an important indicator of consumers' judgments regarding Turkish products. 
H4: When consumers have a higher level of ethnocentrism, their evaluation of Turkish products will be impaired.

Besides, the present study suggests that CE does not only induce inferiority perception about foreign products but also intensify the perceived risk of purchasing these products. In addition to the financial and functional risk that are likely to induce by above-mentioned inferiority beliefs regarding foreign products, $\mathrm{CE}$ also may give rise to serious concerns about social and psychological loss. Because CE provides individual a self of identity and feeling of belongingness (Shimp \& Sharma, 1987), consumers with high ethnocentric tendency are likely to worry that purchasing foreign products will not be approved and lead to losing respect and admiration in their own group. Furthermore, they may also sense the feelings of regret and guilt in the case of purchasing foreign products because they believe it will threaten the survival of the economy and culture of their own country. On this logical ground, it is expected that ethnocentric tendency will provoke the perceived risk of using Turkish products.

H5: When consumers have a higher-level of ethnocentrism, the perceived risk of buying Turkish products will increase.

However, high ethnocentric consumers sometimes prefer domestic products regardless of their perceived superior quality (Sharma et al.,1995), since it is not only an economic but also an ethical issue for them (Shankarmahesh, 2006). Accordingly, even though ethnocentric consumers confirm the general opinion on the superiority of foreign products, they are able to sustain their resistance to buy these products by accentuating positive aspects of domestic products (Suphellen \& Rittenburg, 2001). Hence, although it does not always seem rational, ethnocentric consumers are motivated to favor domestic products because they believe it is good, desirable, appropriate, in short, moral to buy these products (Sharma et al., 1995). So, in addition to its indirect effects, CE is expected to directly influence buying intentions of foreign products. Indeed, literature provides significant evidence that CE promotes reluctance to buy foreign products (Suh \& Kwon, 2002; Nijssena \& Douglas, 2004; Yoo \& Donthu, 2005; Ishii, 2009; Josiassen et al., 2011), preference for a domestic brand/product (Nguyen et al., 2008; Vida \& Reardon, 2008; Vida et al., 2008; Lee, Klobas, Tezinde, \& Murphy, 2010), or at least purchase products imported from culturally similar countries (Watson \& Wright, 2000). Hence, congruent with the well-accepted findings, CE is expected to decrease the intention to buy Turkish products directly.

H6: Consumers with a higher level of ethnocentrism will be less intended to buy Turkish products.

\subsection{Consumer Animosity}

Animosity appears as a construct that enhances the understanding of marketplace effects of consumers' attitudes toward specific producing nation (Klein \& Ettenson,1999). Indeed, as a form of anger (Shaver \& Mikulincer, 2009) or a strong feeling of dislike and enmity (Averill, 1982) towards a particular country, ethnic group or entity (Leong et al., 2008) animosity is expected to have some behavioral expression in the consumption sphere. In this context, Klein et al. (1998) develop a model to investigate the effects of animosity on consumers' purchase decisions in an international marketplace and so provide a conceptual foundation for further research. They defined animosity as "the remnants of antipathy related to previous or ongoing military, political or economic events" and showed that it is an important and powerful predictor of foreign product purchase (Klein et al., 1998: 90).

Past research on animosity toward a country maintained that nature and the content of the concept is pure affective as referring a feeling, emotion of dislike, anger, defiance, hostility, antipathy, rejection with regard to people, customs, ideas, or products from that country (Jung et al., 2002; Jiménez \& Martín, 2012). However, although there is not a prominent classification as cognitive and affective animosity, recent studies conceptualize animosity as an attitude comprising emotion and belief components (Klein et al., 1998; Jung et al., 2002; Leong et al., 2008). The animosity attitude stems from a wide range of reasons from rivalry as a result of sharing a contiguous border to previous military events or recent economic or diplomatic disputes (Klein et. al, 1998) and constantly updated by various events and experiences (Jung et al., 2002). Hoffman, Mai and Smirnova (2011) indicate that perceived economic, military, political or cultural threats to the 
homeland, disapproval of the politics and negative personal experience with the country gave rise to feelings of animosity toward the country. In addition to triggers, there are some factors promoting feelings of animosity toward a country, such as age, union membership, patriotism (Klein \& Ettenson, 1999), responsibility assigned to the citizens of a country for a perceived transgression (Maher \& Mady, 2009), economic hardship believed to be caused by the opposed country, high motivation to blend in with the groups norms (Huang, Phau, \& Lin, 2010).

In literature, consumer animosity is often conceptualized and operationalized as a multidimensional construct considering its various source of manifestation. In their original model Klein et al. (1998) specified war-based and economic-based animosity depending on whether animosity arise from a military and political act or unfair trading practices of a target country that a consumer finds grievous and difficult to forgive. Although there are more recent classifications such as situational versus stable animosity and national versus personal animosity (Jung et al., 2002) the distinction offered by Klein et al. (1998) has been widely adopted. Riefler and Diamantopoulos (2007) assumed that economic animosity feelings would be more salient, more accessible, and consequently more recognizable than historic-based feelings in consumer mind because economic-based feelings have very similar reasons and appear relatively more frequently. Following this assumption, this study focuses on the impact of economic-based animosity on foreign product purchase intention.

Marketing and consumer behavior literature provides significant evidence that animosity reduces willingness and intention to purchase products originated in an offending country (Klein et al., 1998; Klein, 2002) while increasing willingness to pay a premium for the domestic product (Nakos \& Hajidimitriou, 2007). The hindering role of animosity in purchasing foreign products is often investigated simultaneously with the effect of ethnocentrism (e.g. Klein \& Ettenson, 1999; Nijssen \& Douglas, 2004; Ishii, 2009; Cai et al., 2012). Indeed, both constructs provide insights into consumers' decision about purchasing imported products (Klein \& Ettenson, 1999). Consumer animosity and ethnocentrism are alike normative facets of COO effects that both rise from consumers' concerns about the morality of purchasing a product coming from a foreign country (Verlegh \& Steenkamp, 1999) that root in economic and political events (Klein \& Ettenson, 1999). The main feature that distinguishes consumer animosity from ethnocentrism is that animosity is conceptually and theoretically country specific (Klein et al., 2005) while ethnocentrism refers to more general beliefs about all products coming from outside of the own country. Accordingly, non-ethnocentric consumers are expected to find it acceptable to buy foreign products since they are more likely to evaluate products on their own merits (Shimp \& Sharma, 1987).

Klein et al. (1998) also argue that consumer animosity differs from ethnocentrism with regards to its consequences. They suggest that unlike $\mathrm{CE}$, animosity effect foreign product purchase behavior directly and independently of product judgments. Accordingly, consumers with strong feelings of animosity are less willing to purchase the products originated from an opposed country even when they accept the superiority of the product. Subsequent research provides future empirical evidence on the hindering effect of animosity on purchasing a foreign product originated from an offending country (Nijsen \& Douglas, 2004; Leong et al., 2008; Maher \& Mady, 2010; Huang et al., 2010; Hoffman et al, 2011; Wang et al., 2013). However, findings about the role of animosity in product judgments are not so consistent. Some research, particularly studies of Klein et al. revealed that a strong feeling of animosity may directly decrease the purchase intention but does not prompt consumers to derogate quality of the products coming from a hostile country (Klein et al., 1998, Klein, 2002; Nijssen \& Douglas, 2004; Nakos \& Hajidimitriou, 2007; Maher \& Mady, 2010, Wang et al., 2013). On the other hand, Leong et al. (2008) found that not a long-lasting stable animosity but the situational animosity toward a country that arise from a specific circumstance (e.g. an economic crisis) negatively influences both cognitive judgments and affective evaluations of the product coming from the respective country. Subsequently, Huang et al. (2010), Hoffman et al. (2011) found that consumers with high-level animosity perceive that products of an offending country have inferior quality. Considering the congruent evidence provided by the literature we expect that consumers' animosity toward Turkey will reduce the willingness of purchasing Turkish products regardless of product judgments. 
H7: Consumers with a higher level of animosity towards Turkey will have a lower level of intention to buy Turkish products.

However, this study also suggests that animosity have an indirect influence on the intention to buy a product from an offending country through provoking the perceived risk of using these products. It is suggested that consumers feeling a high level of animosity toward a specific country will foresee further adverse consequences associated with using the goods produced in the offending country compared to moderate consumers. Particularly, they are expected to feel the risk of high psychological and social losses. Supporting this expectation Nes, Yelkur and Silkoset (2012) argue that animosity leads to less buying because consumers perceive that buying and consuming products from animosity targets involves negative psychological and social-affective consequences. They indicate that consumers with a high level of animosity toward a country may have negative feelings such as, feelings of discomfort, embarrassment, when purchasing a product originated in that country. Accordingly, consumers may feel discomfort because using these products would be incongruent with their personal image. Furthermore, consumers with a high level of animosity may feel embarrassment because purchasing hostile products are likely to make them the target of negative reactions from people who share the same attitude. Finally, from the morality perspective, they may feel guilty because purchasing a product coming from an opposing country will support its economy (Nes et al., 2012).

Further evidence supporting the increasing effect of animosity on perceived risk comes from the inverse relationship that is documented between animosity and trust in the Jiménez and Martín $(2010,2012)$. They found that animosity is a hindering factor for building trust international marketplace. In other words, consumers who are hostile to a specific country trust far less to the firms originated in that country. On this logical ground, animosity is expected to intensify perceived risk, due to its inverse relationship with trust that is widely emphasized in the literature review on perceived risk research (e.g. Mitchell, 1999; Lim, 2003). On the basis of the discussion, we propose that consumers' animosity toward Turkey will increase the perceived risk of purchasing Turkish products

H8: When consumers have a higher level of animosity towards Turkey, perceived risk of buying Turkish products will increase.

\section{Methodology}

This research aims to investigate the $\mathrm{COO}$ effect on purchase decisions for Turkish products in foreign markets. The required data for testing the research hypotheses were collected through a survey conducted on a sample consisting of 346 native Russian consumers living in Moscow. The convenience sampling method was used, however, Turkish consumers living in Moscow were excluded. Face-to-face interviews were conducted on some famous and busy streets of Moscow.

\subsection{Measurement}

The questionnaire consisted of two parts. The first part included multi-item five-point Likert type scales ( $1=$ definitely disagree, $5=$ definitely agree) for measuring research variables. Three-item scales which are suggested by Lala et al. (2009) was used for measuring the four dimensions of the country image. To assess the ethnocentrism and economic animosity levels of the Russian consumers 6-item scale of Klein et al. (1998) were employed. In addition, the 6-item scale of Klein et al. (1998) was used to assess consumer evaluations regarding Turkish products. The perceived risk of using Turkish products was measured by using six items adapted from the study of Stone and Gronhaug (1993). And finally, a three-item scale for measuring Turkish product purchase intention was drawn from the scale used by Klein et al. (1998). The second part of the questionnaire included the questions asking the age, gender, income and educational levels of the participants. The questionnaire was pretested for clarity through personal interviews with 241 Russian consumers in Moscow. After some minor changes, the final form of the questionnaire was obtained. 


\subsection{Reliability and Validity of Scales}

Both formative and reflective scales were used to measure the constructs in the research model. Thus, a two-stage confirmatory factor analysis (CFA) was conducted with AMOS using the maximum likelihood estimation techniques to assess the measures on validity and reliability. In the first stage, the subdimensions of country image were subjected to the CFA. At the second stage a full measurement model which included three formative scales (country image, product evaluation, and perceived risk) and reflective scales of ethnocentrism, animosity, and purchase intention was tested.

Table 1. Factor Loadings and Reliability Scores

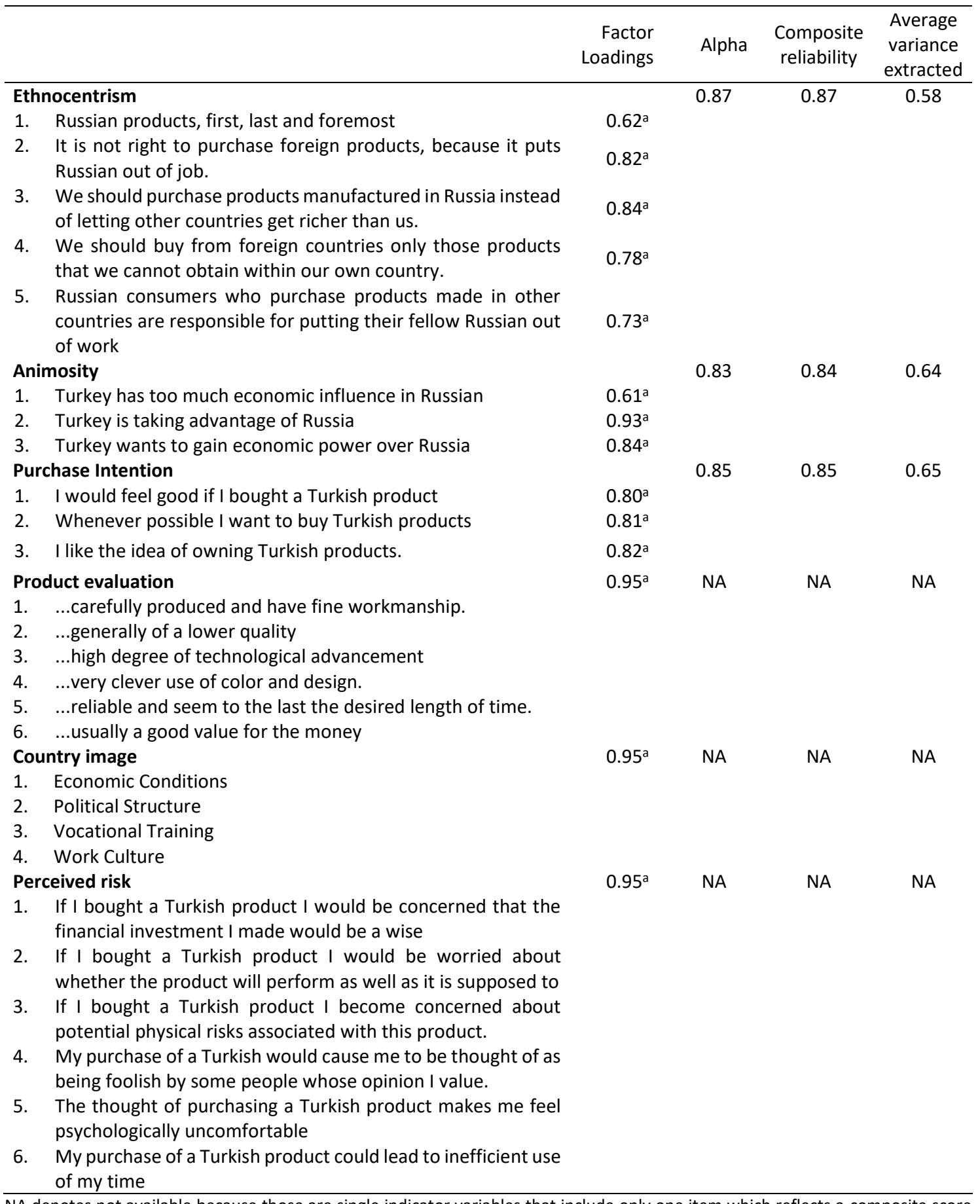

NA denotes not available because those are single indicator variables that include only one item which reflects a composite score of the formative items or sub-dimensions 
The first measurement model included 4 image dimensions as first-order latent factors which include a total of 12 items. Although some goodness-of-fit indices suggest that the model has an acceptable fit (GFI=0.91, NFI=0.91, CFI=0.93), high RMSEA score (0.097) addressed some issues about the model. Three items were eliminated due to their high residual covariance scores. Although this respecified model yielded a significant chi-square statistic $\left(\chi^{2}[21]=60.174\right)$ as usually expected due to the large sample size, goodness-offit indices (GFI=0.96, NFI=0.96, $\mathrm{CFI}=0.97, \mathrm{RMSEA}=0.074$ ) suggest that the model is in line with the observed data. The Cronbach's alpha coefficients were all beyond the critical level of 0.70 that is suggested by Nunnally (1978), providing support for internal consistency (the lowest value is 0.78). At the end of the first stage of the CFA the single indicators of each country image dimension were derived by averaging the items of respective factors. Then a composite score representing country image was created based on the arithmetic mean of these indicators. Moreover, composite scores were obtained to define the products evaluation and overall risk perception by averaging formative items of the constructs.

At the second stage, the full measurement model was subjected to the CFA. This model included composite scores of the country image, product evaluation and perceived risk as single indicant factors in addition to the three multi-item reflective scales of ethnocentrism, animosity, and purchase intention. In the course of model specification measurement error terms for single indicant factors were set at $\% 10$ of their observed variance. CFA on the full measurement model didn't result in a satisfactory fit $\left(\chi^{2}{ }_{[140]}=643.832\right.$, $\mathrm{GFI}=0.84, \mathrm{NFI}=0.83, \mathrm{CFI}=0.86, \mathrm{RMSEA}=0.10$ ). So, the model was respecified by eliminating one item from purchase intention, one item from ethnocentrism and three from animosity due to their high standardized residual covariance and modification indices. CFA revealed that respecified model has an acceptable fit ( $\mathrm{GFI}=0.96, \mathrm{NFI}=0.95, \mathrm{CFI}=0.97, \mathrm{RMSEA}=0.058$ ), while chi-square statistic found to be significant at 0.01 level $\left(\chi^{2}[65]=140.679\right)$. Then, Cronbach's alpha coefficients, composite reliability scores and average variance extracted were calculated to assess the reliability of reflective scales (See Table 2). As all scales had reliability values greater than 0.70 it was concluded that they had adequate reliability (Fornell \& Larcker, 1981; Nunnally, 1978). Additionally, factor loadings of individual items to respective latent constructs were all large and significant $(p<0.01)$ providing evidence for convergent validity.

Table 2. Descriptive Statistics and Latent Factor Intercorrelations

\begin{tabular}{llllllll}
\hline & Mean (sd) & 1 & 2 & 3 & 4 & 5 & 6 \\
\hline 1-Purchase Intention & $2.90(0.84)$ & 1 & & & & & \\
2-Perceived risk & $2.41(0.74)$ & $-0.70^{\mathrm{a}}$ & 1 & & & & \\
3-Product evaluation & $3.14(0.64)$ & $0.71^{\mathrm{a}}$ & $-0.82^{\mathrm{a}}$ & 1 & & & \\
4-Animosity & $2.39(0.76)$ & $-0.17^{\mathrm{a}}$ & $0.37^{\mathrm{a}}$ & $0.37^{\mathrm{a}}$ & 1 & & \\
5-Ethnocentrism & $2.55(0.97)$ & 0.01 & 0.08 & 0.05 & $0.39^{\mathrm{a}}$ & 1 & \\
6-Country Image & $2.80(0.51)$ & $0.53 \mathrm{a}$ & $-0.61^{\mathrm{a}}$ & $-0.61^{\mathrm{a}}$ & $-0.26^{\mathrm{a}}$ & -0.07 & 1 \\
\hline${ }^{\mathrm{a} p<0.01,{ }^{\mathrm{b}} \mathrm{p}<0.05}$ & & & & & & &
\end{tabular}

Finally, in support of the discriminant validity, average variance extracted scores of latent factors were found to be greater than the shared variance between the pairs of constructs. Descriptive statistics for constructs and inter-correlations are provided in Table 2.

\subsection{Test of Hypotheses}

After testing for the reliability and validity of the scales, the structural model including hypothesized relationships was tested using a maximum likelihood method. Analysis yielded acceptable fit statistics (GFI = $0.94, \mathrm{NFI}=0.94, \mathrm{CFI}=0.96$, RMSEA=0.06) supporting the structural model fit with the data although chisquare statistic was found to be significant at 0.01 level as an expected result of large sample size ( $\chi^{2}$ [66] $=155.01)$. Standardized parameter estimates for the hypothesized links are displayed in Table 3. 
Table 3. Standardized Estimates Test Statistics of the Hypothesized Relationship

\begin{tabular}{lllccc}
\hline \multicolumn{2}{c}{ Hypothesized Effects } & $\begin{array}{c}\text { Std. } \\
\text { Estimat } \\
\text { e }\end{array}$ & S.E. & C.R. \\
\hline Perceived risk & $\rightarrow$ & Purchase intention & -0.38 & 0.10 & $-3.89^{\text {a }}$ \\
Product evaluation & $\rightarrow$ & Purchase intention & 0.38 & 0.12 & $3.61^{\text {a }}$ \\
Country Image & $\rightarrow$ & Purchase intention & 0.06 & 0.10 & 0.88 \\
Ethnocentrism & $\rightarrow$ & Purchase intention & -0.01 & 0.05 & -0.25 \\
Animosity & $\rightarrow$ & Purchase intention & 0.10 & 0.05 & 1.79 \\
Product evaluation & $\rightarrow$ & Perceived risk & -0.73 & 0.07 & $-12.36^{\text {a }}$ \\
Country Image & $\rightarrow$ & Perceived risk & -0.10 & 0.09 & -1.63 \\
Ethnocentrism & $\rightarrow$ & Perceived risk & 0.06 & 0.05 & 1.31 \\
Animosity & $\rightarrow$ & Perceived risk & 0.12 & 0.04 & $2.61^{\text {a }}$ \\
Country Image & $\rightarrow$ & Product evaluation & 0.68 & 0.06 & $14.18^{\mathrm{a}}$ \\
Ethnocentrism & $\rightarrow$ & Product evaluation & 0.09 & 0.05 & 1.80 \\
\hline ap<.01 (two-tailed) & & & & &
\end{tabular}

Analysis results confirm that perceived risk and product evaluation are key indicators of purchase intention. Accordingly, perceived product quality increases Russian consumers' intention to buy Turkish products $(B=-0.38, p<0.01)$ while perceived risk hinders the intention $(B=-0.38, p<0.01)$. Product evaluation also has an indirect effect on intention through hindering the risk perception $(\theta=-0.73, p<0.01)$. These findings are consistent with the expectation and common consensus regarding the roles of cues within the frame of information processing (Bettman, 1970).

Figure 1. Analysis Results Analysis of the Conceptual Model

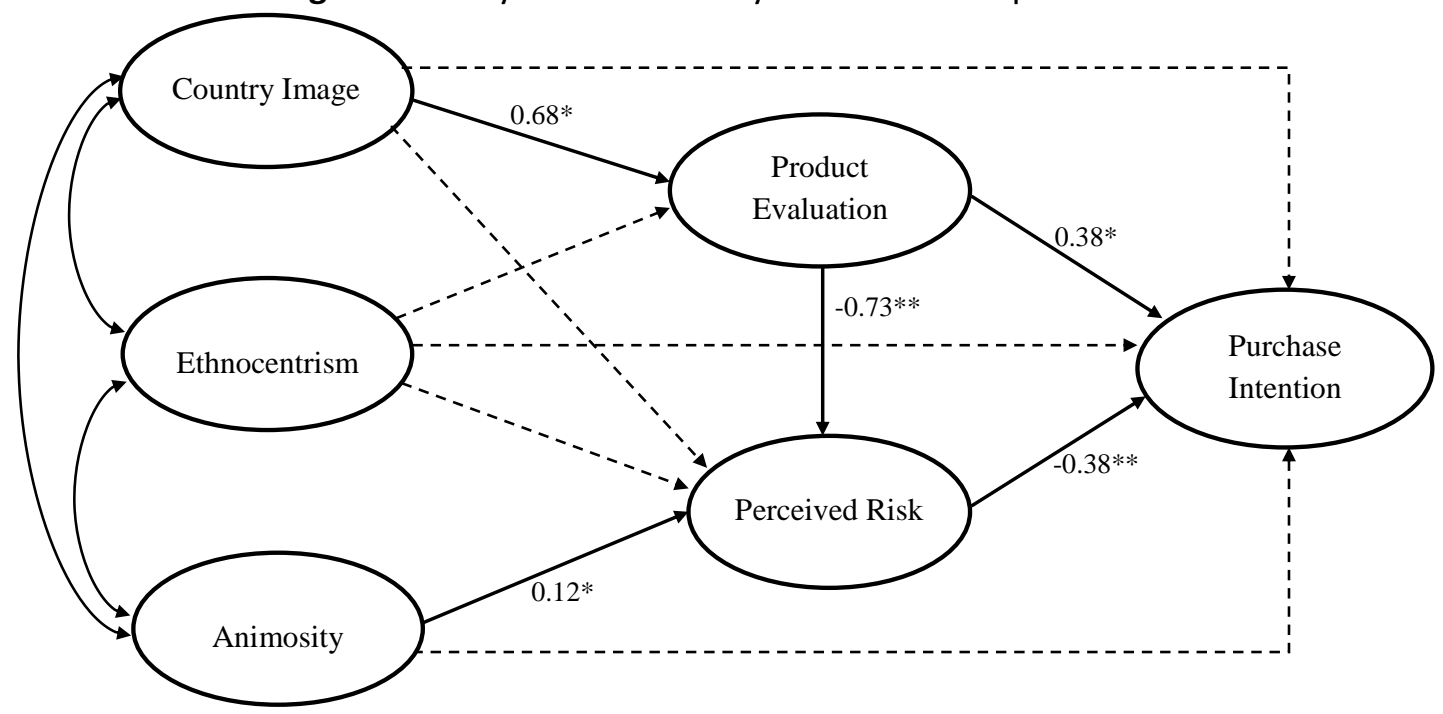

Note: All coefficients are standardized. **Significant for $p<0.01$ (solid lines); dotted line path coefficients are non-significant.

Interestingly, contrary to expectations, the findings show that country image, ethnocentrism and animosity have no significant direct impact on purchase intention. Therefore, H3, H6 and $\mathrm{H} 7$ were not supported. Additionally, $\mathrm{H} 2$ and $\mathrm{H} 5$ couldn't find support since country image and ethnocentrism didn't significantly affect perceived risk. On the other side, animosity was found to be positively related with perceived risk of using Turkish products in accordance with the $\mathrm{H} 8(\theta=0.12, p<0.01)$. $\mathrm{H} 1$ was also confirmed because findings showed that country image is a strong predictor of product evaluation $(B=0.68, p<0.01)$. Finally, the parameter estimate for the link between ethnocentrism and product evaluation was found to be nonsignificant at 0.05 level, so H4 wasn't supported. Furthermore, results revealed that animosity is 
positively related to ethnocentrism $(r=0.39, p<0.01)$ and negatively related to the image of the country $(r=-$ $0.28, p<0.01$ ) (see Table 2).

Overall, although only 5 of 11 hypothesized relations were supported, the proposed model had a high level of explanatory power as revealed by the squared multiple correlations. Accordingly, the model explains $46 \%$ of the observed variance in product evaluation, $69 \%$ of the perceived risk and $56 \%$ of Turkish product purchase intention.

\section{Discussion}

Considering the role of export for firm performance and economic growth in macro level, it is a strategic requirement to improve the competitive position of Turkish firms in the global marketplace. "Country of origin effect" referring to the origin-country-related bias toward foreign products (Samiee, 1994), is one of the considerations to be taken into account in this context. In the global market, consumers are supplied a set of non-domestic products in various categories and it is well-known fact that their responses are affected by the origin of the product (e.g. Nagashima, 1970; Bilkey \& Nes, 1982; Han \& Terpstra, 1988; Kaynak \& Kara, 2002). Here "Country of origin effect" may have a promoting or impairing effect on the competitive position of Turkish firms. So, it is critical, more than ever, to understand consumers' general preferences, attitudes, and evaluations of the product originated from Turkey. This study specifically focuses on Russian consumers and aim to give additional insight into how origin related factors influence their choices for Turkish products. Both theoretical and empirical studies on $\mathrm{COO}$ effect revealed that when buying foreign products, some specific factors affect consumers' buying decision (See, Liefeld 1993 for review). The role of some of these factors including country image, $\mathrm{CE}$, and animosity on Russian consumers' product evaluation, risk perception and finally buying intention for Turkish products are investigated in this study.

The most striking finding of the study is that Russian consumers' products evaluation and risk perception are the key factors on their decisions to accept or reject the Turkish products. Indeed, information processing model points out their roles for purchase decisions regardless of the origin. The interesting point is that contrary to our expectation $\mathrm{COO}$ related factors (i.e., country image, $\mathrm{CE}$, and animosity) had no direct influence on purchase intention for Turkish products. Indeed, they don't even exert all indirect effects we expected. For example, surprisingly, none of the proposed impacts of ethnocentrism was statistically significant. It was found to have no impact on neither product evaluation, nor risk perception. This finding contradicts with most extant literature on CE (Klein et al., 1998; Klein 2002; Suh \& Kwon, 2002; Nijssen \& Douglas, 2004; Nguyen et al., 2008; Ishii, 2009; Funk, Arthurs, Treviño, \& Joireman, 2010), but in line with some other studies (García-de-Frutos \& Ortega-Egea, 2015). Actually, Russian consumers reported a fairly low level of ethnocentrism $(M=2.55$ and $S S=0.97)$ which is fueled by animosity $(r=0.39, p<0.01)$. From a marketing perspective, a low level of ethnocentric bias is advantageous for the firms that plan to enter the Russian consumer market. Russian consumers, even who believe they should buy domestic products as a first choice, appear to be rational and do not underestimate the quality of Turkish products.

On the other hand, as expected, animosity was found to intensify risk perception although it did not directly avert the purchase intention. Accordingly, strong feeling of anger, dislike or enmity against Turkey may yield a higher level of risk perception. Although, animosity toward Turkey was found to be low ( $M=2.39$, $\mathrm{SS}=0.76)$ and its indirect total impact is rather weak, our results revealed the impeding influence of macrolevel ongoing military, political or economic issues between the two countries on micro (individual) level evaluations.

Finally, but most importantly, analysis results uncover the role of "Turkey image" on the way to preferences for Turkish product in the Russian market. It must be noted that in this study, the country image is conceptualized following the halo effect perspective and referred to an overall attitude which is formed by the perceptions regarding it's economic, political and technological elements (Kotler \& Gertner, 2002; Lee \& Ganesh, 1999). Although the country image was found to have no significant effect on risk perceptions and purchase intention, results offer overwhelming evidence for its impact on Russian consumers' product evaluations. Indeed, this finding is consistent with that of Erickson, Johansson, and Chao (1984) who assert 
that country image just influences consumer's product evaluation, not their purchase intention. Additionally, findings showed that Russian consumers' attitudes toward Turkey didn't have an alleviative influence on risk perception. However, consistent with the previous findings (e.g. Samiee, 1994; Van Ittersum, Candel, \& Meulenberg, 2003) Russian consumers' attitudes toward Turkey has an impact on their product evaluation. Accordingly, when Russian consumers evaluate Turkey in a favorable way, they evaluate Turkish products as having a superior product quality. The significant amount of the shared variance (approximately $50 \%$ ) indicates the strong link between country and product evaluation. Considering the multinational conceptualization of the country image, it is safe to state that country image has some affective and cognitive impacts on evaluations. For example, image dimensions regarding economic conditions, vocational training, and work culture provide some cognitive cues for product evaluations. More specifically, when Russian consumers believe that Turkish workers are well educated, hard- working and attentive to details they are more prone to think Turkish products to be high quality, durable, and provide a high product value. Here, a general belief about qualities, attributes, and characteristics of Turkish workers play a role of heuristic for making inferences about product quality. In a similar vein, the consumers, who think that Turkey is a modern and technologically advanced country, infer that the products that are made in Turkey will be technologically advanced. Moreover, perceptions regarding the political structure of Turkey as related to democracy, peace, and freedom may also contribute to product evaluation through an affective route. It appears that attitudes towards governments of other countries and the workers living in that country bias the general evaluation about the products through cognitive or affective routes.

\section{Conclusion}

The purpose of this study was to gain insights about which country-of-origin related factors influence the evaluation and purchase intention of Turkish products in international markets. Since the impact may differentiate depending on the target markets, the study focused on Russian consumer market, specifically. The findings revealed that none of the country-of-origin related factors (neither ethnocentrism, animosity nor country image) do directly increase or decrease purchase intention for Turkish products. This may be attributed to the Russian consumers' high level of familiarity to specific Turkish products (e.g. textile products) which alleviate the asserted negative impact of conflicts between two countries.

Although not all hypotheses are supported, the research convincingly demonstrated that a general image of the origin country plays a critical role in product evaluation. Finding strongly suggests that "image of Turkey" has an important role in international marketing performance of Turkish firms since it influences the perceived product value. One implication of these results is that before entering a market abroad, Turkish firms should asses the "Turkey image" in the market, and then define the eventual marketing advantages or disadvantages that arise from the image. Target market's favorable opinion of Turkey enables to promote the products while a negative country image builds attitudinal and behavioral barriers for the purchase of the products which indeed is a significant challenge for marketing managers. Considering the importance of international competitiveness, a "grouping" of proactive and systematic efforts by government agencies and industry associations will be beneficial to build a positive country image through foreign promotion campaigns (Papadopoulos, 1993) which will help to avert building future barriers to entering new markets or overcome some existent barriers.

Finally, several limitations of this research should be mentioned. The study focuses solely on the Russian market and a general "Turkish product" evaluation. Clearly, additional research will be necessary to further understand the perceptions regarding the various product categories that are produced in Turkey. Besides, a replication of the current results in different markets abroad would provide useful insights for practitioners that target other international markets. 


\section{Acknowledgement}

The authors would like to sincerely thank the anonymous reviewers for their insightful comments and suggestions on an earlier version of this manuscript.

\section{References}

Agarwal, S., \& Teas, R. K. (2001). Perceived value: Mediating role of perceived risk. Journal of Marketing Theory and Practice, 9(4), 1-14.

Akdeniz Ar, A., \& Kara, A. (2014). Emerging market consumers' country of production image, trust and quality perceptions of global brands made-in China. Journal of Product \& Brand Management, 23(7), 491-503.

Alden, D. L., Steenkamp, J-B. E. M., \& Batra, R. (2006). Consumer attitudes toward marketplace globalization: Structure, antecedents and consequences. International Journal of Research in Marketing, 23, 27-239.

Amonini, C., Keogh, J., \& Sweeney, J. C. (1998). The dual nature of country-of-origin effects-a study of Australian consumers' evaluations. Australasian Marketing Journal (AMJ), 6(2), 13-27.

Averill, J. (1982). Anger and aggression: An essay on emotion. New York: Springer-Verlag.

Aydın, F., Saygılı, H., \& Saygılı, M. (2007). Empirical analysis of structural change in Turkish exports. The Central Bank of the Republic of Turkey (No. 07/08). Working Paper.

Balabanis, G., Diamantopoulos, A., Mueller, R., \& Melewar, T. C. (2001). The impact of nationalism, patriotism and internationalism on consumer ethnocentric tendencies. Journal of International Business Studies, 32(1), $157-175$.

Balabanis, G., Melewar, T. C., \& Mueller, R. (2002). The relationship between consumer ethnocentrism and human values. Journal of Global Marketing, 15(3/4), 7-37.

Bettman, J. R. (1970). Information processing models of consumer behavior. Journal of Marketing Research, 8, $370-376$.

Bilkey, W. J., \& Nes, E. (1982). Country-of-origin effects on product evaluations. Journal of International Business Studies, 13(1), 89-100.

Bizumic B., Duckitt J., Popadic D., Dru V., \& Krauss, S (2009). A cross-cultural investigation into a reconceptualization of ethnocentrism. European Journal of Social Psychology, 39, 871-899.

Buhmann, A. (2016). Measuring country image. Springer Fachmedien Wiesbaden.

Cai, H., Fang, X., Yang, Z., \& Song, H. (2012). Implicit consumer animosity: A primary validation. Journal of Applied Social Psychology, 42(7), 1651-1674.

Canli, Z. G., \& Maheswaran, D. (2000). Cultural variations in country of origin effects. Journal of Marketing Research, 37(3), 309-317.

Cleveland, M., Laroche, M., \& Papadopoulos, N. (2009). Cosmopolitanism, consumer ethnocentrism, and materialism: An eight-country study of antecedents and outcomes. Journal of International Marketing, 17(1), 116-146.

De Ruyter, K., Van Birgelen, M., \& Wetzels, M. (1998). Consumer ethnocentrism in international services marketing. International Business Review, 7(2), 185-202.

Demirbag, M., Sahadev, S., \& Mellahi, K. (2010). Country image and consumer preference for emerging economy products: The moderating role of consumer materialism. International Marketing Review, 27(2), 141-163.

Elliott, G. R., \& Cameron, R. C. (1994). Consumer perception of product quality and the country-of-origin effect. Journal of international Marketing, 49-62.

Erickson, G. M., Johansson, J. K., \& Chao, P. (1984). Image variables in multi-attribute product evaluations: Country-oforigin effects. Journal of Consumer Research, 11(2), 694-699.

Fornell, C., \& Larcker, D. F. (1981). Evaluating structural equation models with unobservable variables and measurement error. Journal of Marketing Research, 18(1), 39-50.

Funk, C. A., Arthurs, J. D., Treviño, L. J., \& Joireman, J. (2010). Consumer animosity in the global value chain: The effect of international production shifts on willingness to purchase hybrid products. Journal of International Business Studies, 41(4), 639-651.

García-de-Frutos, N., \& Ortega-Egea, J. M. (2015). An integrative model of consumers' reluctance to buy foreign products: do social and environmental country images play a role? Journal of Macromarketing, 35(2), 167-186.

Genç, B., \& Bayraktaroğlu, A. G. (2017). Exploring the country of origin effect: A qualitative analysis of Turkish consumption practices. In Qualitative Consumer Research (pp. 25-50). Emerald Publishing Limited. 
Griffith, D. A., \& Czinkota, M. R. (2012). Release the constraints: Solving the problems of export financing in troublesome times. Business Horizons, 55(3), 251-260.

Han, C. M. (1989). Country image: Halo or summary construct. Journal of Marketing Research, 26(2), 222-229.

Han, C. M., \& Terpstra, V. (1988). Country-of-origin effects for uni-national and bi-national products. Journal of International Business Studies, 19(2), 235-55.

Hoffmann, S., Mai, R., \& Smirnova, M. (2011). Development and validation of a cross-nationally stable scale of consumer animosity. Journal of Marketing Theory and Practice, 19(2), 235-251.

Huang, Y., Phau, I., \& Lin, C. (2010). Consumer animosity, economic hardship, and normative influence: How do they affect consumers' purchase intention? European Journal of Marketing, 44(7/8), 909-937.

Hult, G. T. M., \& Keillor, B D. (1994). The impact of a social desirability bias on consumer ethnocentrism research: A cross-national perspective. The Journal of Marketing Management, 4(2), 48-55.

Ishii, K. (2009). Nationalistic sentiments of Chinese consumers: The effects and determinants of animosity and consumer ethnocentrism. Journal of International Consumer Marketing, 21, 299-308.

Javalgi, R. G., Khare, V. P., Gross, A. C., \& Scherer, R. F. (2005). An application of the consumer ethnocentrism model to French consumers. International Business Review, 14, 325-344.

Jiménez, N. H., \& San Martín, S. (2010). The role of country-of-origin, ethnocentrism and animosity in promoting consumer trust. The moderating role of familiarity. International Business Review, 19(1), 34-45.

Jiménez, N., \& Martín, S. S. (2012). Emerging markets commerce: The role of country-of-origin and animosity in purchase intention. International Journal of Business and Management, 7(17), 34-42.

Josiassen, A., Assaf, A. G., \& Karpen, I. O. (2011). Consumer ethnocentrism and willingness to buy: Analyzing the role of three demographic consumer characteristics. International Marketing Review, 28(6), 627-646.

Jung, K. Ang, S. H., Leong, S. M., Tan, S.J., Pornpitakpan, C., \& Kau, A. K. (2002). A typology of animosity and its crossnational validation. Journal of Cross-Cultural Psychology, (33), 525-539.

Kaynak, E., \& Kara, A. (2002). Consumer perceptions of foreign products: An analysis of product-country images and ethnocentrism. European Journal of Marketing, 36(7/8), 928-949.

Klein, J. G. (2002). Us versus them, or us versus everyone? Delineating consumer aversion to foreign goods. Journal of International Business Studies, 33(2), 345-363.

Klein, J. G., Ettenson, R., \& Morris, M. D. (1998). The animosity model of foreign product purchase: An empirical test in the People's Republic of China. The Journal of Marketing, 89-100.

Klein, J. G. \& Ettenson, R. (1999). Consumer animosity and consumer ethnocentrism: An analysis of unique antecedents. Journal of International Consumer Marketing, 11(4), 5-24.

Kleppe, I. A., Iversen, N. M., \& Stensaker, I. G. (2002). Country images in marketing strategies: Conceptual issues and an empirical Asian illustration. Journal of Brand Management, 10(1), 61-74.

Knight, G. A., \& Calantone, R. J. (2000). A flexible model of consumer country-of-origin perceptions: A cross-cultural investigation. International Marketing Review, 17(2), 127-145.

Koo Kim, C. (1995). Brand popularity and country image in global competition: Managerial implications. Journal of Product \& Brand Management, 4(5), 21-33.

Kotler, P., \& Gertner, D. (2002). Country as brand, product, and beyond: A place marketing and brand management perspective. Journal of Brand Management, 9(4), 249-261.

Kumcu, E., Harcar, T., \& Kumcu, M. E. (1995). Managerial perceptions of the adequacy of export incentive programs: Implications for export-led economic development policy. Journal of Business Research, 32(2), 163-174.

Lala, V., Allred, A. T., \& Chakraborty, G. (2008). A multidimensional scale for measuring country image. Journal of International Consumer Marketing, 21(1), 51-66.

Lee, D., \& Ganesh, G. (1999). Effects of partitioned country image in the context of brand image and familiarity: A categorization theory perspective. International Marketing Review, 16(1), 18-41.

Lee, R., Klobas, J., Tezinde, T., \& Murphy, J. (2010). The underlying social identities of a nation's brand. International Marketing Review, 27(4), 450-465.

Lee, T. S., \& Chen, F. F. (2008). Country image effect on Taiwanese consumers' willingness to buy from neighboring countries. International Journal of Commerce and Management, 18(2), 166-183. 
Leong S. M., Cote J. A., Ang S.H., Tan S. J. , Jung K., Kau A.K., \& Pornpitakpan C. (2008). Understanding consumer animosity in an international crisis: Nature, antecedents and consequences. Journal of International Business Studies, 39, 996- 1009.

Leonidou, L. C. (1995). Empirical research on export barriers: Review, assessment, and synthesis. Journal of International Marketing, 3(1), 29-43.

Leonidou, L. C. (2000). Barriers to export management: An organizational and internationalization analysis. Journal of International Management, 6(2), 121-148.

Liefeld, J. P. (1993). Experiments on country-of-origin effects: Review and meta-analysis of effect size. In N. Papadopoulos and L. Heslop (Ed.), Product Country Images: Impact and Role in International Marketing (pp. 117156). International Business Press, New York, NY.

Lim, N. (2003). Consumers' perceived risk: sources versus consequences. Electronic Commerce Research and Applications, 2, 216-228.

Lumpkin, J. R., Crawford, J. C., \& Kim, G. (1985). Perceived risk as a factor in buying foreign clothes: Implications for marketing strategy. International Journal of Advertising, 4(2), 157-171.

Maher, A. A., \& Mady, S. (2010). Animosity, subjective norms, and anticipated emotions during an international crisis. International Marketing Review, 27(6), 630-651.

Martin, I. M., \& Eroglu, S. (1993). Measuring a multi-dimensional construct: Country image. Journal of Business Research, 28(3), 191-210.

Mitchell, V. W. (1999). Consumer perceived risk: Conceptualisations and models. European Journal of Marketing, 33(1/2), 163-195.

Nagashima, A. (1970). A comparison of Japanese and US attitudes toward foreign products. The Journal of Marketing, 34(1), 68-74.

Nakos, G. E., \& Hajidimitriou, Y. A. (2007). The impact of national animosity on consumer purchases: The modifying factor of personal characteristics. Journal of International Consumer Marketing, 19(3), 53-72.

Nes, E. B. Yelkur, R., \& Silkoset, R. (2012). Exploring the animosity domain and the role of affect in a cross-national context. International Business Review, 21, 751-765.

Nguyen, T. D., Nguyen T.T.M., \& Barrett, N. J. (2008). Consumer ethnocentrism, cultural sensitivity, and intention to purchase local products: Evidence from Vietnam. Journal of Consumer Behaviour, 7, 88-100.

Nijssen, E. J., \& Douglas, S.P. (2004). Examining the animosity model in a country with a high level of foreign trade. International Journal of Research in Marketing, 21, 23-38.

Nunnally, J. (1978). Psychometric methods. New York: McGraw Hill.

Olson, J. C., \& Jacoby, J. (1972). Cue utilization in the quality perception process. ACR Special Volumes.

Özbay, F. (2011). The Relations between Turkey and Russia in the 2000s. Perceptions, 16(3), 69.

Papadopoulos, N. (1993). What product and country images are and are not. In N. Papadopoulos and L. A. Heslop (Ed.), Product-country images impact and role in international marketing (pp.3-38). The Haworth Press, Binghamton.

Porter, M.E. (1990). The Competitive Advantage of Nations. Harvard Business Review, March-April, 73-91.

Ranjbarian, B., Barari, M., \& Zabihzade, K. (2011) Ethnocentrism among Iranian consumer with different consumption habits. International Journal of Marketing Studies, 3(3), 30-41.

Riefler, P., \& Diamantopoulos, A. (2007). Consumer animosity: A literature review and a reconsideration of its measurement. International Marketing Review, 24(1), 87-119.

Rybina, L., Reardon, J., \& Humphrey, J. (2010). Patriotism, cosmopolitanism, consumer ethnocentrism and purchase behavior in Kazakhstan. Organizations and Markets in Emerging Economies, 1(2), 92-107.

Samiee, S. (1994). Customer evaluation of products in a global market. Journal of International Business Studies, 25(3), 579-604.

Saran, R., \& Gupta, N. (2012). Country of origin vs. consumer perception: A literature review. IUP Journal of Marketing Management, 11(4), 66-75.

Shankarmahesh, M. N. (2006). Consumer ethnocentrism: An integrative review of its antecedents and consequences. International Marketing Review, 23(2), 146-172.

Sharma, S., Shimp, T. A., \& Shin J. (1995). Consumer ethnocentrism: A test of antecedents and moderators. Journal of the Academy of Marketing Science, 23(1), 26-37. 
Shaver, P. R., \& Mikulincer, M. (2009) Attachment styles. In M. R. Leary and R. H. Hoyle (Ed.), Handbook of individual differences in social behavior (pp. 62-81). New York, NY: Guilford Press.

Shimp, T. A. (1984). Consumer ethnocentrism: The concept and a preliminary empirical test. ACR North American Advances.

Shimp, T. A., \& Sharma, S. (1987). Consumer ethnocentrism: Construction and validation of the CETSCALE. Journal of Marketing Research, 280-289.

Spillan, J. E., Kang, Z., \& Barat, S. (2011). A multi-country study exploring relationships of lifestyles to ethnocentrism. Journal of Transnational Management, 16(2), 62-83.

Stone, R. N., \& Grønhaug, K. (1993). Perceived risk: Further considerations for the marketing discipline. European Journal of Marketing, 27(3), 39-50.

Suh, T., \& Kwon, I. W. G. (2002). Globalization and reluctant buyers. International Marketing Review, 19(6), 663-680.

Sumner, G. A. (1906). Folkways. New York: Ginn Custom Publishing.

Supphellen, M., \& Rittenburg, T. L. (2001). Consumer ethnocentrism when foreign products are better". Psychology \&Marketing, 18(9), 907-927.

Şimşek, N., Şimşek, H. A., \& Zhanaltay, Z. (2017). Analysis of bilateral trade relations between Turkey and Russia federation. Bilig, 83, 1-26.

Turkish Statistical Institute (2018, June 29). Foreign Trade Statistics. Retrieved from: http://www.tuik.gov.tr/PreHaberBultenleri.do?id=27788.

Usunier, J. C. (2006). Relevance in business research: The case of country-of-origin research in marketing. European Management Review, 3(1), 60-73.

Van Ittersum, K., Candel, M. J., \& Meulenberg, M. T. (2003). The influence of the image of a product's region of origin on product evaluation. Journal of Business Research, 56(3), 215-226.

Verlegh, P. W., \& Steenkamp, J. B. E. (1999). A review and meta-analysis of country-of-origin research. Journal of Economic Psychology, 20(5), 521-546.

Vida, I. Dmitrovic', T., \& Obadia, C. (2008). The role of ethnic affiliation in consumer ethnocentrism. European Journal of Marketing, 42(3/4), 327-343.

Vida, I., \& Reardon, J. (2008). Domestic consumption: Rational, affective or normative choice? Journal of Consumer Marketing, 25(1), 34-44.

Wang, W., He, H., \& Li, Y. (2013). Animosity and willingness to buy foreign products: Moderating factors in decisionmaking of Chinese consumer. Asia Pacific Business Review, 19(1), 32-52.

Wang, C. K., \& Lamb, C. W. (1980). Foreign environmental factors influencing American consumers' predispositions toward European products. Journal of the Academy of Marketing Science, 8(4), 345-356.

Watson, J. J., \& Wright, K. (2000). Consumer ethnocentrism and attitudes toward domestic and foreign products. European Journal of Marketing, 34 (9/10), 1149-1166.

Yoo, B., \& Donthu, N. (2005). The effect of personal cultural orientation on consumer ethnocentrism: Evaluations and behaviors of US consumers toward Japanese products. Journal of International Consumer Marketing, 18(1-2), 744. 
This Page Intentionally Left Blank 